\title{
Mathematical Research on Optimization Technique for Diet Planning Problem: Case Research Autism Paralympic Athlete
}

\author{
Natasha A M Zailani, Suliadi F Sufahani, Mustafa Mamat
}

\begin{abstract}
This paper demonstrates distinctive methods used in operation research to experience with different diet issues. Every diet problem has its particular cost limitation and objective function. The designation of sufficient menus including the consideration of several types of constraints, for example, the ideal nutritional content, the amount of food to be consumed and others. The mathematical model is constructed to determine a diet plan as an optimal solution which fulfills every requirements and limitations. The application of different optimization techniques and weakness in each method has been reviewed. The use of integer programming and development that can be done also represents in this paper. An optimal and practical solution is acquired to solve the diet problem for autism Paralympic athlete.

Index Terms - Autism, diet problem, integer programming, operation research, Paralympic athlete.
\end{abstract}

\section{INTRODUCTION}

Everybody knows the important of a balanced and nutritious diet in a daily life. A balanced diet is vital for every humankind in order maintain good health and body condition. This diet incorporates an assortment of nourishments to provide essential nutrients such as carbohydrate, proteins, vitamins, minerals, fat and fibers to our body. Autism Spectrum Disorders (ASD) are described by a complex of a genuine neurodevelopmental disorders, classified as symptoms of the Pervasive Development Disorders group (PDD). It is described by difficulties with speech (delayed employment of language), abnormalities of posture or gesture, problems with understanding the feelings of others, sensory and visual misperceptions, fears and anxieties, and behavioural abnormalities such as compulsive/obsessive behaviour and ritualistic movements [3], [4], [7], [9], [22], [28], [29]. Based on [8], epidemiological data estimates the presence of 52 million cases of autism worldwide, affecting around $1 \%-2 \%$ of children across the globe. And thereby, around 12, 785 of autism patients which has been registered throughout the Malaysia until $30^{\text {th }}$ Mac 2016 regarding to the statistics made in Jabatan Kebajikan Masyarakat Malaysia (Malaysian Welfare Department) reported by Utusan, 2016 [20], [30].

Natasha Amira Mohd Zailani, Department of Mathematics and Statistic, Faculty of Applied Sciences and Technology, Universiti Tun Hussein Onn Malaysia, Pagoh Campus, 84600 Pagoh, Johor, Malaysia.

Suliadi Firdaus Sufahani, Department of Mathematics and Statistic, Faculty of Applied Sciences and Technology, Universiti Tun Hussein Onn Malaysia, Pagoh Campus, 84600 Pagoh, Johor, Malaysia.

Mustafa Mamat, Faculty of Informatics and Computing, Universiti Sultan Zainal Abidin, Kampung Gong Badak, 21300 Kuala Terengganu, Terengganu, Malaysia.
Revised Manuscript Received on July 10, 2019.

Autism patients confronted their concern in choosing the diet that meet the nutrition requirements especially in sports area because the needed of additional nutrient in the body for tournaments preparation is higher than a normal body. We do not find any study on applying optimization approach in addressing the dietary problem for autism Paralympic athlete, however, there is developing proof that nourishing treatment can truly have a major effect on autism patients. Many have extremely disturbed digestion, so restoring balance in the gut is a key focus for nutritional treatment Also important is balancing blood sugar, checking for brainpolluting heavy metals, excluding food additives, identifying food allergies and possible nutrient deficiencies, and ensuring an optimal intake of essential fats. The diet planning for autism Paralympic athlete included the optimization technique in order to make a proper decision making to overcome this diet problem. Besides, planning of sufficient menus including the consideration of several types of constraints such as the ideal nutritional content, the amount of food to be consumed and their food allergens.

\section{LITERATURE REVIEW}

According to the interactive case study in [1] which is started by Optimization Technology Centre (OTC), the diet problem including the formation of the mathematical model, application of optimization technique to deal with problem and formulation of strategies and solutions. Furthermore, in [10] were explored the optimization of diet problem for athlete which Two main objectives that is the panning menu meeting nutritional requirements of athletes and keep those expenditure assigned for athletes staying with the fixed budget. The aim of the study is to prepared the weekly menu for strengthen the athletes' performance during the tournament period. The formation of strong athletes' physical is completely depended on the well-planned diet menu.

\section{A. Linear Programming}

An optimization study is to study the food choice of French women to prepare the balanced meal with the cost constraint. Linear programming technique is utilized to find the food combination is optimal in nutrition with the minimal cost. Based on [3], there are 476 of French women from different socioeconomic levels as the sample for this study. The diets were created by linear programming 


\section{MATHEMATICAL RESEARCH ON OPTIMIZATION TECHNIQUE FOR DIET PLANNING PROBLEM: CASE RESEARCH AUTISM PARALYMPIC ATHLETE}

method which is Simplex approach of the Premium Solver Platform 5.0 for Excel. Furthermore, a linear programming model to satisfy a week of foreordained nutritional requirements and economical combination of food such as chicken, macaroni, spaghetti, and more. The acquired result is a repetitious diet that included only 46.667 packages of macaroni and cheese with the minimal consumption at $\$ 88.20$. Then, the AMPL model is been modified and elaborated for this diet problem as the solution is on the desired solution. The diet modification are adequate vary from previous outcomes. The diet presently contains 19.5 packages of chicken, 16.3 packages of macaroni and cheese, and 4.3 of meatloaf. In any case, the cost expanded from $\$ 88.20$ to $\$ 89.99$. Such modification to the linear program will produce an adequate solution in solving the diet problem [6]. Then, the application of Linear Programming method is in advancement in numerous investigation and fields. It is regularly used to encounter personnel management problem, agricultural problem, allocation of aircraft, diet problem and significantly more. Additionally, it can likewise use to decide fish feed mixes and consequently to raise the production of fishes and minimize the cost (in Indian Rupee) for formulation of fish feed. The model was developed which comprised 7 variables which are the quantity in $\mathrm{kg}$ of groundnut cake, soya bean cake, rice-bran, wheat bran, fish meal, brewer waste, til cake required for the formulation of the fish feed [12]. The constraints for this model:

- Protein (not less than 38\%)

- Lipid (not less than 6\%)

- Carbohydrate (not less than 26\%)

- Calcium (not less than $1 \%$ )

- Phosphorous (not less than $0.6 \%$ )

- Amount needed (The sum for the food item as fish feed is $100 \mathrm{~kg}$ )

In this case, the linear programming technique to develop the feed formulation is more proficient and compelling than the conventional method such as experimentation method that produces in lower productivity of fishes.

\section{B. Integer Programming}

Basically, an integer value is more representative for the food items intake is in whole units rather than non-integer value. In consequence, integer programming is organized to construct the planning diets for humans at minimum cost. Apart from that, it is used to describe logically the relationship between frequency of food usage, exchange groups and the amount of energy of different meals. Eventually, the linear equations were developed which are used to explaining these interactions. The diet related problem was generated further by the application of this algorithm based on numerous types of basic foods that meet the nutritious requirements for certain group of people [18]. Moreover, in [17] was implemented with a scientific approach to choose appropriate food items that can reduce the expenses, without violating the need to meet the desired nutrient quantities, avoiding food allergens and getting certain foods into the diet problem of eczema patients from young age group. 426 food items are considered into the daily menu planning for this study. Along with to provide a complete menu planning for one day for eczema patients.
Table 1: Summary of previous study

\begin{tabular}{|c|c|}
\hline $\begin{array}{c}\text { Reference } \\
\text { s }\end{array}$ & Technique and Research Problems \\
\hline$[6]$ & $\begin{array}{l}\text { To produce a linear programming model to } \\
\text { achieve a week of fixed nutritional } \\
\text { requirements and cheapest packages } \\
\text { combination of food such as chicken, } \\
\text { macaroni, spaghetti and so on. } \\
\text { The linear programming model could not } \\
\text { fulfill all the constraints that leads to an } \\
\text { optimal solution. }\end{array}$ \\
\hline [3] & $\begin{array}{l}\text { To investigate the food choice of French } \\
\text { women from different socioeconomic levels } \\
\text { to prepare the balanced meal with the cost } \\
\text { constraint by using a linear programming } \\
\text { technique. } \\
\text { The solution for the French women from low } \\
\text { economic level may not practical; the meal } \\
\text { planning is not familiar in their families and } \\
\text { not designed according to their preference. }\end{array}$ \\
\hline$[12]$ & $\begin{array}{l}\text { To find out fish feed compounds and in return } \\
\text { to raise the productivity of fishes and the } \\
\text { profit earning by the fishes. In this case, the } \\
\text { linear programming method to produce the } \\
\text { feed formulation. } \\
\text { The upper bounds for the nutrient contents do } \\
\text { not consider in the research. }\end{array}$ \\
\hline [13] & $\begin{array}{l}\text { Suggested a goal programming method which } \\
\text { to enhance healthy nutrition menu planning } \\
\text { which within the household food budget } \\
\text { expenditure. } \\
\text { The menu planning is designed only for daily } \\
\text { needs, and thus the food variety is not } \\
\text { considered. }\end{array}$ \\
\hline [11] & $\begin{array}{l}\text { Suggested a Fuzzy Linear Programming for } \\
\text { planning diet menu for Eating Disorder and } \\
\text { Disease-related lifestyle. } \\
\text { Some macronutrients are not taken account in } \\
\text { this research. Therefore, there is lack of } \\
\text { nutrients in the menu planning. }\end{array}$ \\
\hline [5] & $\begin{array}{l}\text { To produce a fuzzy linear programming } \\
\text { method for those patients which can fulfill } \\
\text { their nutrition requirements in the fuzzy } \\
\text { environment. The fuzzy concept is applied on } \\
\text { account of the facts that there is uncertain in } \\
\text { the amount of nutrients intake. } \\
\text { There are some sentences when using this } \\
\text { technique owing to that the fuzzy logic may } \\
\text { not reflect the realities. }\end{array}$ \\
\hline
\end{tabular}




\begin{tabular}{|c|l|}
\hline$[19]$ & $\begin{array}{l}\text { To generate a mathematical integer } \\
\text { programming method for diet planning that } \\
\text { meets the necessary nutrient intake for the } \\
\text { secondary school student as well as } \\
\text { minimizing a budget. } \\
\text { The planning menus for school children based } \\
\text { on the cost of food items and RDA for } \\
\text { children aged between 13 to 18 years old is } \\
\text { not consider in this study. }\end{array}$ \\
\hline$[14]$ & $\begin{array}{l}\text { Implemented the optimization research by } \\
\text { using an integer programming technique } \\
\text { about the nutritional ingredient needed by the } \\
\text { human whose age between 40 to 45 and to } \\
\text { minimize the cost of total diet. }\end{array}$ \\
\hline$[17]$ & $\begin{array}{l}\text { Implemented integer programming approach } \\
\text { to choose suitable food items that can } \\
\text { minimize the expenses, meets desired nutrient } \\
\text { quantities, avoid food allergens and getting } \\
\text { right foods into the diet problem of eczema } \\
\text { patients from young age group. } \\
\text { The solution deal with the diet problem of } \\
\text { eczema patients. }\end{array}$ \\
\hline$[16]$ & $\begin{array}{l}\text { To generate a nonlinear programming model } \\
\text { for optimizing the use in nutrient } \\
\text { requirements in the diet planning. } \\
\text { The nonlinear programming method is } \\
\text { impractical to apply since it encounters } \\
\text { enormous solution algorithms and complex } \\
\text { mathematical theory. }\end{array}$ \\
\hline
\end{tabular}

The diet problem can be written as follows:

$c_{1} x_{1}+c_{2} x_{2}+c_{3} x_{3} \ldots+c_{n} x_{n}$

Subject to the constraints:

$$
\begin{gathered}
a_{11} x_{1}+a_{12} x_{2}+a_{13} x_{3}+\ldots+a_{1 n} x_{n} \geq b_{1}, \\
a_{21} x_{1}+a_{22} x_{2}+a_{23} x_{3}+\ldots+a_{2 n} x_{n} \geq b_{2}, \\
a_{m 1} x_{1}+a_{m 2} x_{2}+a_{m 3} x_{3}+\ldots+a_{m n} x_{n} \geq b_{m},
\end{gathered}
$$

where $a_{m n}$ is the value of constraints $m$ in variable $x_{n}$.

Different human ages have various nutritious requirement needed. The nutritional food needed by the human who aged between 40 to 45 as well as to minimize the total diet cost at the same time was carried out by the optimization research area. There are some nutritional constraints that should be complied such as the range of specific nutrients needed.

Table 2: Contributions and development of the research using Integer Programming

- To prepare menu to meet certain nutritional requirement

- To find out the balanced nutrient desired by the autism Paralympic athletes

- To find the optimal and practical solution

- To produce a complete menu planning for one day

- The ranges of nutritional requirement are described.

- Included all essential vitamins and minerals in the meal.
- 426 food items are selected into the daily menu planning

- The solution is customized for the autism Paralympic athletes

\section{Goal Programming}

An extension or generalization of linear programming to handle multiple, normally conflicting objective measures which denote as a goal programming. In [13] suggested a model which to improve healthy nutritious menu planning which within the household food budget expenses. This study was done from February to March in the capital of Bosnia and Herzegovina. The questionnaires was answered by the selected 50 random samples of household. In that review, the sample concerned consists of 55 most common consumed food items as decision variables. To reduce the deviation of World Organization recommended daily nutrients desired to the greatest extend and subject to the household expenses constraints, they then generated a goal programming model on it. The objective function in this model using goal programming method:

$$
\text { Minimize } Z=\sum_{i=1}^{n}\left(d_{i}^{-}+d_{i}^{+}\right)
$$

where $d_{i}^{-}$and $d_{i}^{+}$are positive and negative deviational variables that indicate the deviations from the $i$ th goal. For the RNI constraints positive deviation $d_{i}^{+}=0$, while for the UL constraints negative deviation $d_{i}^{-}=0$.

\section{Fuzzy Programming}

To find the solution of diet problem faced by renal patients also can be solved by optimization technique. Basically, a patient intake too much salt, protein and others in the diet can cause the kidney disease become worsen. Consequently, Fuzzy Linear Programming is used to develop a model for those patients which can satisfy their nutrition needed in the fuzzy environment. With the facts that there is uncertain in the amount of nutrients intake, the fuzzy concept will be applied on it [5]. Furthermore, from [11], the application of Fuzzy Linear Programming in planning diet menu for Eating Disorder and Disease-related lifestyle. The computation of the amount of nutrients desired which subjected to some constraints was involved on this technique [23]-[27].

\section{E. Nonlinear Programming}

The weakness of linear programming of objective function for diet designation can be solved by the nonlinear programming [16]. Sometimes, the assumptions for all variables are linear are not practical and result of solution for the diet problem is limitation. Also, it can be used to formulate a model which develops the diet that produce a minimum cost as well as linear programming. It included a complex methods which is the minimum square relation between responding variable and explanatory variables of

Published By:

Blue Eyes Intelligence Engineering 
various degrees are carried out as to design the nonlinear programming model. And thus, to find the best fit relation between the variables, F-test will be employed.

\section{DISCUSSIONS \& RESULTS}

This section will focus the previous study and the disadvantages of each finding. The recommended method and the expansion of the mathematical model of the Malaysian menu planning problem are then will be discussed. Table 1 shows the distinction of previous study and the disadvantages of each study. Various techniques have been employed in the application of the menu planning problem with different objectives and constraints as shown in the previous study. Further development need to be done and Table 2 represents the contributions that can be recognized in this research.

\section{CONCLUSION}

The outlay of the food menu can be minimized by applying the integer programming technique. Besides verifying the healthy diet which supplies all the essential minerals and vitamins, the feasible solution is also formulated for the autism Paralympic athletes to plan their diet menu as stated to the mathematical model. The study helped to understand the human nutrients needed and the used of integer programming to get a good and optimal diet. Further study can be developed to provide balanced diet menu that satisfies nutritional needs for autism Paralympic athletes form age 20 until 35. Moreover, even more effort in conducting the research on investigating the knowledge of food intolerance, food and their respective nutritional value and to nurture a healthy lifestyle

\section{ACKNOWLEDGMENT}

The authors thank the referees for their supportive comment on improving the script. Thank you to Universiti Tun Hussein Onn Malaysia (UTHM) for the GPPS.

\section{REFERENCES}

1. J. Czyzyk, T. Wisniewski, and S. J. Wright, "Optimization case studies in the NEOS Guide," SIAM Review, 41(1), 1999 , pp. 148-163.

2. D. M. Crowley, "Autism Spectrum Disorders (ASD) diagnosis, therapies and their perceived effectiveness-extract from a report of a parent survey," Journal of the Australasian College of Nutritional and Environmental Medicine, 28(3), 2009, pp. 11-16.

3. N. Darmon, E. L. Ferguson, and A. Briend, "Impact of a cost constraint on nutritionally adequate food choices for French women: An analysis by linear programming," Journal of nutrition education and behavior, 38(2), 2006, pp. 82-90.

4. C. J. Dover, and A. L. Couteur, "How to diagnose autism," Archives of Disease in Childhood, 92(6), 2007, pp. 540-545.

5. H. Eghbali, E. Abdoos, S. Ashtiani, and M. Ahmadvand, "Modeling the optimal diet problem for renal patients with fuzzy analysis of nutrients," International Journal of Management and Fuzzy Systems, 1(1), 2013, pp. 7-14.

6. R. Fourer, D. M. Gay, and B. W. Kernighan, AMPL: A Modelling Language for Mathematical Programming. California: Thomson/Brooks/Cole and Duxbury Press, 2003.

7. A. M. Grabrucker, "Environmental factors in autism," Frontiers in Psychiatry, 3, 2013, pp. 1-13.
8. E. M. Hahler, and M. Elsabbagh, "Autism: A global perspective," Current Developmental Disorders Reports, 2(1), 2015, pp. 58-64.

9. I. Hertz-Picciotto, L. A. Croen, R. Hansen, C. R. Jones, J. van de Water, and I. N. Pessah, "The CHARGE study: An epidemiologic investigation of genetic and environmental factors contributing to autism," Environmental Health Perspectives, 114(7), 2006, pp. 1119-1125.

10. D. Magdić, J. G. Kljusurić, L. Matijević, and D. Frketić, "Analysis of diet optimization models for enabling conditions for hypertrophic muscle enlargement in athletes," Croatian Journal of Food Science and Technology, 5(1), 2013, pp. 18-28.

11. M. Mamat, N. F. Zulkifli, S. K. Deraman, and N. M. M. Noor, "Fuzzy linear programming approach in balance diet planning for eating disorder and disease-related lifestyle," Applied Mathematical Sciences, 6(103), 2012, pp. 5109-5118.

12. T. Nath, and A. Talukdar, "Linear programming technique in fish feed formulation," International Journal of Engineering Trends and Technology, 17(3), 2014, pp. 132-135.

13. M. Pasic, A. Catovic, I. Bijelonja, and A. Bahtanovic, Goal programming nutrition optimization model," 23rd International DAAAM Symposium, 2012, pp. 243-246.

14. A. N. Patil, and S. Kasturi, "Optimal diet decision using linear programming," International Research Journal of Engineering and Technology, 3(8), 2011pp. 2197-2199.

15. I. Rapin, "Autism in search of a home in the brain," Neurology, 52(5), 1999, pp. 902-902.

16. P. Saxena, "Comparison of linear and nonlinear programming techniques for animal diet," Applied Mathematics, 1(2), 2010, pp. 106-108.

17. L. Z. Sheng, and S. Sufahani, "Optimal diet planning for Eczema patient using Integer Programming," Journal of Physics: Conference Series, 995(1), 2018, pp. 1-8.

18. D. Sklan, and I. Dariel, "Diet planning for humans using mixed-integer linear programming," British Journal of Nutrition, 70(1), 1993, pp. 27-35.

19. S. Sufahani, and Z. Ismail, "A new menu planning model for Malaysian secondary schools using optimization approach," Applied Mathematical Sciences, 8(151), 2014, pp. 7511-7518.

20. Utusan Online, 12,785 golongan autism berdaftar dengan JKM. Available: http://m.utusan.com.my/berita/wilayah/12785-golongan-autisme-berdaftar-dengan-jkm-1.219119.

21. H. V. Pena, and H. M. Alfaro, "Menu planning using the exchange diet system," IEEE International Conference on Systems, Man and Cybernetics, 2003, pp. 3044-3049.

22. D. Jayeola, Z. Ismail, S. F. Sufahani, and D. P. Manliura, "Optimal method for investing on assets using Black Litterman Model," Far East Journal of Mathematical Sciences, 101(5), 2017, pp. 1123

23. S. Sufahani, and Z. Ismail, "The statistical analysis of the prevalence of pneumonia for children age 12 in west Malaysian hospital," Applied Mathematical Sciences, 8(114), 2014, pp. 5673-5680.

24. S. Sufahani, N. Che-Him, A. Khamis, M. S. Rusiman, N. Arbin, C. K. Yee, I. N. Ramli, N. A. Suhaimi, S. S. Jing, and Z. A. Azmi, "Descriptive statistics with Box-Jenkins and marketing research for jewellery company in Malaysia," Far East Journal of Mathematical Sciences, 101(10), 2017, pp. 2151-2161.

25. S. F. Sufahani, and A. Ahmad, "A comparison between normal and non-normal data in bootstrap," Applied Mathematical Sciences 6(89-92), 2012, pp. 4547-4560. 
26. M. S. Rusiman, O. C. Hau, A. W. Abdullah, S. F. Sufahani, and N. A. Azmi, "An analysis of time series for the prediction of Barramundi (Ikan Siakap) price in Malaysia," Far East Journal of Mathematical Sciences, 102(9), 2017, pp. 20812093.

27. Z. Ismai, N. Abu, and S. Sufahani, "New product forecasting with limited or no data," AIP Conference Proceedings, 1782(1), 2016, pp. 1-8.

28. S. Sufahani, M. G. Kamardan, M. S. Rusiman, M. Mohamad, K. Khalid, M. Ali, K. Khalid, M. K. M. Nawawi, and A. Ahmad, "A mathematical study on "additive technique" versus "branch and bound technique" for solving binary programming problem," Journal of Physics: Conference Series, 995(1), 2018, pp. 1-8.

29. M. Ali, S. Sufahani M. G. Kamardan, and Z. Ismail, "A new diet scheduling model for Malaysian school children using zero-one optimization approach," Global Journal of Pure and Applied Mathematics, 12(1), 2016, pp. 413-419.

30. A. Zinober, and S. Sufahani, "A non-standard optimal control problem arising in an economics application," Pesquisa Operacional, 33(1), 2013, pp. 63-71. 